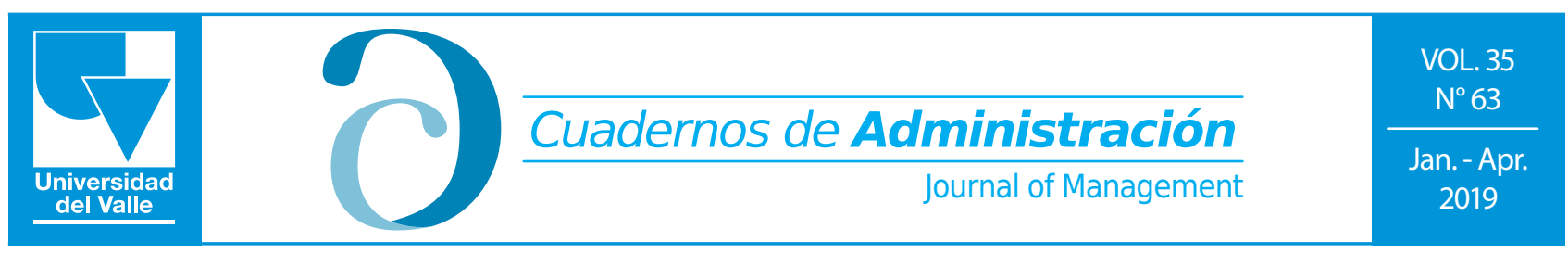

Print ISSN: 0120-4645 / E-ISSN: 2256-5078 / Short name: cuad.adm. / Pages: 101-113

Faculty if Administration Sciences / Universidad del Valle / Cali - Colombia

\title{
The instruments of public policy. A transdisciplinary look
}

\author{
Los instrumentos de política pública. Una mirada transdisciplinar \\ Instruments de politique publique. Une vision transdisciplinaire
}

\begin{abstract}
María Helena Franco Vargas ${ }^{1}$
Professor, Department of Government and Political Science, School of Humanities, Universidad EAFIT, Medellín, Colombia. ORCID iD: https://orcid.org/0000-0002-8076-3934.e-mail: mafranco@eafit.edu.co
\end{abstract}

Daniela Roldán Restrepo ${ }^{2}$

Analyst Consultant, Centro de Análisis Político (Center for Political Analysis, Department of Government and Political Science, School of Humanities, Universidad EAFIT, Medellín, Colombia.

ORCID iD: https://orcid.org/0000-0001-8577-8978. e-mail: droldanr@eafit.edu.co

$\begin{array}{r}\hline \text { Review Article, PUBLINDEX-COLCIENCIAS classification } \\ \text { Submitted: } 04 / 09 / 2018 \\ \text { Reviewed: } 16 / 10 / 2018 \\ \text { Accepted: } 14 / 12 / 2018 \\ \text { Core topic: Administration and Organizations, public policy } \\ \text { JEL classification: A12, H83 } \\ \text { DOI: https://doi.org/10.25100/cdea.v35i63.6893 } \\ \hline\end{array}$

\begin{abstract}
The implementation of public policies involves knowing and analyzing the different instruments of public intervention from a transdisciplinary perspective involving legal, economic and political aspects, as this allows to broaden the understanding of the tools available to deal with public issues. In this sense, this paper seeks to present in an integrative and systematic way what have disciplines such as public law, the economy of the public sector and the political sciences, especially public policies, understood for public policy instruments. It takes a particular look at this latter approach and shows why this is the most comprehensive approach. Regarding the methodology, this text is the product of qualitative, theoretical, descriptive and exploratory research of a documentary nature. Among the main findings, intervention instruments were found to guide human behavior towards achieving certain public objectives, constitute the rules of the game and, therefore, serve as institutions that illuminate public action. They are also tools to correct market failures and achieve economic efficiency. Nevertheless, they are not limited to the formal technical and institutional two-dimensional nature of economics and law. Nowadays, the study of intervention instruments must be done in accordance with public policies; it must enable progressing towards context-sensitive governments, the diversity of actors, more active citizenship and the particularities of public affairs.
\end{abstract}

Keywords: Public intervention instruments, Public policy instruments, Government instruments, Governance, Public policies.

\section{Resumen}

La implementación de las políticas públicas implica conocer y analizar los distintos instrumentos de intervención pública desde una mirada transdiciplinar que involucre aspectos jurídicos, económicos y politológicos, pues esto permite

1 Lawyer, Universidad de Medellín, Colombia, Master in Law and Economics, Universidad de Buenos Aires, Argentina.

2 Sociologist, Universidad de Antioquia, Medellín, Colombia. 
ampliar la comprensión frente a las herramientas disponibles para afrontar los problemas públicos. En este sentido, este trabajo busca presentar de manera integradora y sistemática qué han entendido por instrumentos de política pública disciplinas como el derecho público, la economía del sector público y las ciencias políticas, en especial las políticas públicas. Se detiene de manera particular en este último enfoque y muestra por qué éste es el más abarcador. Con relación a la metodología, este texto es producto de una investigación cualitativa, teórica, descriptiva y exploratoria de carácter documental. Dentro de los principales hallazgos se encuentra que los instrumentos de intervención orientan el comportamiento humano hacia el logro de ciertos objetivos públicos, constituyen reglas de juego y, por tanto, sirven como instituciones que iluminan la acción pública. También son herramientas para corregir fallas del mercado y conseguir la eficiencia económica. Sin embargo, no se limitan a la bidimensionalidad técnica e institucional formal propias de la economía y del derecho. Hoy el estudio de los instrumentos de intervención se debe hacer de acuerdo a las políticas públicas, debe permitir el avance hacia gobiernos sensibles a los contextos, a la diversidad de actores, a una ciudadanía más activa y a las particularidades de los problemas públicos.

Palabras clave: Instrumentos de intervención pública, Instrumentos de política pública, Instrumentos de gobierno, Gobernanza, Políticas públicas.

\section{Résumé}

La mise en œuvre des politiques publiques implique la connaissance et l'analyse des différents instruments d'intervention publique d'un point de vue transdisciplinaire qui entraîne des aspects juridiques, économiques et politiques, car cela permet une meilleure compréhension des outils disponibles pour faire face aux problèmes publics. En ce sens, le présent document cherche à présenter de façon intégrée et systématique ce que des disciplines comme le droit public, l'économie du secteur public et les sciences politiques, en particulier les politiques publiques, ont compris comme des instruments de politique publique. II examine en particulier, cette dernière approche et montre pourquoi est la plus complète. Sur le plan méthodologique, ce texte est le fruit d'une recherche qualitative, théorique, descriptive et exploratoire de nature documentaire. L'une des principales conclusions est que les instruments d'intervention orientent le comportement humain vers la réalisation de certains objectifs publics, constituent des règles du jeu et, par conséquent, servent d'institutions qui éclairent l'action publique. Ils sont également des outils pour corriger les défaillances du marché et atteindre l'efficacité économique. Cependant, elles ne se limitent pas à la formalité technique et institutionnelle bidimensionnelle de l'économie et du droit. Aujourd'hui, l'étude des instruments d'intervention doit se faire en conformité avec les politiques publiques, et doit permettre de progresser vers des gouvernements sensibles aux contextes, à la diversité des acteurs, à une citoyenneté plus active et aux spécificités des problèmes publics.
Mots clés: Instruments d'intervention publique, Instruments de politique publique, Instruments de gouvernement, Gouvernance, Politiques publiques.

\section{Introduction}

Recent research on State theory, public administration, public policy, and public sector economics have shown a series of transformations in the face of the different ways in which the State intervenes to solve public problems. Thus, nowadays it is necessary to take into account aspects such as: that the State model determines the public administration model (Ariño, 2003, p. 301), that it is necessary to move from governments through plans, programs and projects to governments through public policies (Aguilar, 2013, p. 30), that the study of public matters requires reckoning not only the sphere of state-related affairs formal institutional - but also the constant interrelations between the state, the market, non-governmental entities and the community (Fontaine, 2015, p. 63), and that the way governments govern is determined by the type of tools and instruments used for their actions.

This work focuses on the latter aspect, that is, on the instruments of public intervention and aims to address them from a transdisciplinary perspective, which articulates legal proposals (particularly from the public finances), political proposals (from the public policy approach) and public economics, since while it is increasingly sought to strengthen the disciplinary identity of each of these fields, it is also necessary to work in a transversal way and to draw bridges that permit, among other things, to diversify the approach, to use research methods and techniques that make it possible to approach the subject matter of study in another way in order to understand more comprehensively public problems and to propose more equitable, efficient and effective solutions and policy recommendations. This will allows the interpretation matrix to be expanded in the light of the various means whereby the State intervenes in order to solve public issues. In other words, the objective of this paper is to explain what public intervention instruments are, what different theoretical fields such as public finance, public economics and public 
policies understand by them, and what is the contribution of this latter approach, from the realm of governance.

In this sense, this paper combines different perspectives in order to analyze the most recent findings, perspectives, orientations and discussions regarding public policy instruments. It should be clarified that, although in the literature there are works from the point of view of each of the aforementioned disciplines, there are no studies that address in a systematized and holistic way the analyses of public intervention instruments. For this reason, it is important to perform a literature review wherein contemporary studies on these tools are identified and integrated in order to provide an account of the state of the art in this matter.

Regarding the methodology, this work is the product of documentary-nature theoretical, descriptive and exploratory research, since the procedure involved the tracing, characterization, systematization and analysis of a set of texts on the instruments of public intervention. The research technique was a documentary review. The analysis units were documents on the subject found in libraries, specialized databases, scientific or academic publications and included descriptors such as government instruments, public intervention tools, devices for public action, implementation of policies, among others, both in English and Spanish, as research criteria. For organization, systematization and selection of information a database was created in Excel, then triangulation was conducted with interviews with experts and discussion groups.

This work has three parts: the first one approaches the instruments of intervention from the perspectives of law, particularly from public finances, public economics and public policies. It also addresses the different definitions given by the literature regarding intervention instruments and shows the main typologies that have been worked out on in this regard. The second part sets forth some arguments in favor of the political approach about intervention instruments and calls for the construction of active citizenships with a view to the use of intervention instruments under the governance approach. Lastly, the conclusions are presented.

\section{Theoretical framework}

\subsection{A look at public intervention instruments}

One of the major contemporary challenges faced by governments is to reform their structures so that market, state and governance failures (Jessop, 2002, p. 275) be corrected in such a way that state action meets the various challenges it faces, such as decentralizing, deconcentrating, deregulating, reducing the size of the bureaucratic apparatus, the direct supply of certain goods and services, the production of quality institutions that achieve the realization of rights, the redistribution of income and wealth, the reduction of poverty, etc. Since the instruments of intervention are the mechanisms through which these challenges are addressed, the discussion about them takes on special relevance.

On the other hand, the approach that different disciplines make to these issues has led to different conceptions of what are the instruments of public intervention. In other words, various legal theories (constitutional law, administrative law or public finance), economics (neoclassical economics or public sector economics) and political theories (Weberian, new governance, postmanagement models or neo-Weberian) have studied through a different lens the subjects of transformation, modernization of the State and the ways of action of Governments, which has led to a dissimilar conception of how governments govern and through what tools they do it. This can be seen in the way in which different definitions of instruments of public intervention coexist - often without speaking to one another.

Thus, in general terms, legal definitions refer to public intervention instruments as the different forms of State action that "arise progressively in the historical process of expansion of ends by the State. In assuming new ends, which is a political issue, which is before and outside administrative law, the State needs new instruments for intervention" 
(Ariño, 2003, p. 287). By virtue of the principle of legality, these forms of State action are contained in the various types of legal norms through which the voices of law express themselves. That is, through laws, decrees, agreements, ordinances, regulations, contracts, resolutions, circulars, among others. Thus, each form of intervention, each instrument for State action, is immersed in the formal institutional arrangement that contains it: the legal norm.

It should be noted, however, that new approaches to public law, especially in the field of public finance, recognize other forms of State action involving a greater or lesser bureaucratic apparatus, the formation of public enterprises or, on the contrary, the conclusion of contracts with third parties, the granting of state insurance and other promotional activities, such as public credit, transfers and subsidies, as well as the design of comprehensive tax systems or tax incentives. In this sense, a group of works in which this perspective prevails outstands within the national legal literature. Thus, the research by the tax and economic law departments of the Universities Externado and Javeriana have dealt with topics such as: economic regulation, public home utilities, public intervention, administrative regulation and public finance (see in particular the works of Atehortúa, 2009; Miranda and Márquez, 2004; Restrepo, 2015). The Universidad del Rosario has addressed in a special way the topics related to tax and fiscal law (Insignares, Marín, Muñoz, Piza, and Zornoza, 2007). Likewise, at the Universidad de Antioquia and EAFIT, work has been undertaken on the role of the public and the private, as well as on the so-called escape of administrative law, wherefrom the texts of Marín (2008) and Suárez (2010) become important.

In particular, landowners such as Restrepo (2015) and Plazas (2005), along the lines of classics such as Musgrave (1994), claim that intervention instruments are the means that States use to meet the purposes or ends of public finances. In this sense, intervention instruments are widely understood as devices through which public goods and services are provided, income and wealth redistributed, the economy stabilized and social, economic and environmental sustainability achieved (p.27).
In short, these works highlight the fact that the challenge of recent decades has been not only to drift from purely state-nature instruments to other private instruments which has been catalogued by authors such as Balbín (2015), Santofimio (1998) and Suárez (2010) as the "flight of administrative law" or, in the words of Bobbio (1997), as "privatization of the public" (p. 14) - but also to achieve balance, proper combination and coordination between different instruments of intervention to solve of public problems. (Ariño, 2003, p. 133).

As far as the economy is concerned, definitions that conceive instruments as solutions to market imperfections are reckoned. Faced with this, there are two great positions that highlight an orthodox and a heterodox look. The first is based on the neoclassical theory (Mankiw, 2012; Phelps, 1999; Varian, 2005) according to which state intervention instruments are market corrective, i.e. they are only used when the market alone has not achieved economic efficiency results. In other words, they have a residual nature. This view underscores the idea that markets can, by themselves, produce efficient results and correct their own imperfections. The logic under which state intervention is justified only in extreme cases where this does not happen. In this regard, we highlight the position of authors such as Coase (2002) for who even doing nothing is an instrument of intervention by the State (e.g. 528).

The second look, the heterodox one, is typical of public sector economics, and it highlights the works of authors such as Stiglitz and Rosengard (2016) who conceive government intervention instruments as corrective mechanisms for imperfections within the context of mixed economies. For these authors, the use of intervention tools is justified not only for economic reasons, related to the correction of market imperfections and the achievement of efficiency but also for social and political reasons, such as unemployment, poverty, inequality, government failures or the public election process. Therefore, they assure that it is necessary to try to "find the way for the state and the markets to act together, reinforcing each other" (p. 40). Thus, one of the main tasks faced by governments today 
is to solve public problems, for which it is necessary to recognize that the problems included in the agenda, the objectives of the policies and the instruments of intervention used to implement them are determined by the type of State, models of public administration and the functions, purposes and ends of public finances. In this sense, the authors argue that the objectives of public administration and the different correlations of forces established between government, economy and institutions will be decisive for the types of intervention (Stiglitz and Rosengard, 2016).

Finally, political science and, in particular, public policies are the discipline and subdiscipline that have in recent years been most devoted to the analysis of intervention instruments in a specific and focused manner, to the point of making them a subject of study (Salamon, 2002). For this reason, there is no consensus on a basic number of instruments for public intervention or on how they can be understood. In one of the first works within the national literature identifying public policy instruments, Leyva and Tabares (2015) show how Kirschen et al. count up to 64 instruments such as those of the politics they study, while in an effort to make a more generic list Linder and Peters (1989) indicate that there are seven basic instruments available for public intervention. Later on, in the seminal book of which he is the editor, Salamon (2002) presents 14 instruments as the most widely used by the government, a list that for Leyva and Tabares "can be expanded to more than 30 or 40 instruments" (2015, p. 273).

In addition to the lists, within the public policy literature, there are also different ways of understanding or defining what instruments of public intervention are. Thus, the more general definitions are: "they are artifacts to carry out an activity, a means or a set of means to achieve an end" (Fontaine, 2015, p. 86) or those that highlight the Statesociety relationship: they are "technical and social devices that structure public action by organizing the specific relations between the
State and the citizenship" (Lascoumes and Le Galès, 2007, p. 4).

There are also some definitions that underline the fact that instruments of public intervention do not exist as a given reality but as social and analytical constructions: they are "ideal categories that group unequal initiatives used in a combined manner by policymakers" (Velasco, 2007, p. 1). On the other hand, there are those that emphasize the power of the government actor: they are "the set of techniques through which government authorities exercise their power in the attempt to secure support and to effectuate or prevent social change" (Vedung, 1998, p. 21). As well as definitions that implicitly integrate multiple characteristics: an instrument is "an identifiable method through which collective action is structured to deal with a public problem ${ }^{1 "}$ (Salamon, 2002, p. 19).

However, although lists and definitions may vary, there is consensus on at least two aspects in the literature that is limited to political science and, in particular, public policy. The first is the importance bestowed upon instruments not only as tools for public intervention, but also as tools for the analysis of these interventions. Analyses that emphasize the instruments are both "professional" or for politics, as "academic" or policy, and although "the border between the two types is not as sharp" (Roth, 2017, p. 80), there is a strong development of this latter type of analysis - especially in the global North -, unlike what happens in the other disciplines set out above.

The second aspect in which there is convergence between those who study the instruments of public intervention from political science and/or public policies, is related to the effort made to understand public action in all its complexity and, therefore, to overcome the automatic linkage of the notion of public intervention to direct government (bureaucratic apparatus, state agencies, public enterprises, etc.). This happens when recognizing that:

1 According to the author, there are several characteristics associated with this definition: first, those instruments are defined as identifiable methods means that they have common and intrinsic characteristics. Secondly, when we say that the instruments structure the action, we assume that these are "institutions", that is, regularized patterns of interaction between individuals and organizations. Thirdly, it should be said that action structured by instruments is collective action and implies that not only governments are involved. (Salamon, 2002, p.19). 
When government activity was previously restricted to the direct provision of goods and services through its bureaucracies, it now encompasses a dizzying array of loans, loan guarantees, subsidies, contracts, social regulations, economic regulations, insurance, tax spending, bonds, and more. (Salamon, 2002, p. 2).

Faced with this latter convergence, it is worth mentioning the views that bridge economics and political science by authors such as Weimer and Vining (2017, p. 209) and Ballart and Ramió (2000, p. 487). These refer to intervention instruments as a means to solve market failures such as the lack of provision of public goods (pure and meritorious), externalities, natural monopolies and asymmetric information. They also argue that, through these intervention tools, it is possible to restore the efficiency status of markets, without disregarding, however, elements that enable an analysis of instruments that surpasses the mere efficiency explanation such as context, values and interests of decision makers, place of enunciation or perspective of decisionmaking, agenda processes, implementation and the different interactions of the actors involved in the process.

In short, today the new paradigms of State theory, public administration, public finances, public policies and the public economy place responsibility for delivering goods and services in an equitable, effective and efficient manner, not only on the state bureaucratic apparatus, but also on the agents of the private sector who, for instance, through contracts with third parties, assume this commitment and perform public tasks. Therefore, it is now more necessary to speak of intervention, action or public policy instruments rather than "government instruments".

\section{Theoretical development}

\subsection{Intervention instruments under the focus of public policies and governance}

From what has been tackled so far, the legal perspective is found to often confuse the instrument of public policy with the vehicle of delivery or institutional agreement (the legal norm itself), which forms a formal institutional view that conceives instruments as rules of play that shape and discipline the behaviors. The economy, on the other hand, risks identifying intervention instruments with devices to correct market imperfections. It is an instrumental and technical approach to the extent that they are conceived as a means to achieve economic efficiency, although the heterodox visions described above are recognized.

In contrast, the political science approach is more comprehensive because it understands that instruments are not only the legal norm or the vehicle of delivery, nor are they merely the technical tool conceived by the economy, devoid of ideological considerations, context or political processes. It assumes that intervention instruments compromise decision-making on the courses of action, which concerns not only the most efficient way of solving a particular public issue but also the relative influence that several affected interests will have on developments following promulgation or implementation of the courses of action (Salamon, 2002, p. 11).

In a context where political, social and economic actors with the capacity to influence public decision-making proliferate, the issue of instruments is therefore not secondary. The regulation of relations between these actors (governance) is a challenge faced by current governments, especially after the failure of neoliberal policies in the 1980s and 1990s. For this reason, Bardach (2009) suggests that the wide range of tools that Governments have to do their tasks and strike a balance between them should be identified. Because of its broad understanding of what instruments are and their implications for political, economic and legal processes, the public policy approach makes such identification and balance possible.

On the other hand, the understanding of the instruments under the eyes of public policies makes it possible to think about them at different times in the courses of public action. Thus, according to Hood (2006) there are at least three approaches that allow the analysis of instruments throughout the public policy cycle in different ways: the 
first, wherein Salamon's (2002) work stands out, is the one that conceives instruments as institutions, that is, as regularized forms of State-society interaction available to government throughout the cycle, such as hiring freelancers or private sector entities, consolidating public corporations and, in general, various forms of public-private partnership. The second approach, for the analysis of instruments, is that which focuses on the political, ideological or cognitive processes behind the selection of instruments, an approach developed mainly by Linder and Peters (1989, 1992, 1998). Finally, the third approach is one that classifies instruments into generic typologies whose origin can be traced from the pioneering work of Dahl and Lindblom (1953) on the set of socio-economic instruments used by the government, to the work of a large number of proponents, including McDonnell and Elmore (1987), Schneider and Ingram (1990), Weimer and Vining (2017), Doern and Phidd (1992), Vedung (1998), Hood (1983) himself and more recently, Salamon (2002), Velasco (2007), Howlett, Kim, and Weaver (2006), Howlet and Mukherjee (2017), Lascoumes and Le Galés (2007, 2016), Sunstein (2014), Pal (2014), among others.

The typologies approach is one of the most widely used nowadays, although a review of the main texts within the literature of public policy instruments is prompt to show that there are as many typologies as authors who elaborate them, as can be seen in Table 1. As tools for the analysis of and for policies, these typologies are quite useful, insofar as they facilitate the task of organizing the "toolbox" that a government has for its better understanding and, therefore, managing the complexity involved for the analyst to determine the instruments of those policies under study, since they rarely appear in a pure form. Likewise, the typologies allow the classification of instruments according to general characteristics that they share and whose relevance is likely to be determined according to the objectives of the inquiry. Hence, while the vast majority of authors use as classifier the resources that are used to specify the instruments, others emphasize the drivers behind their choosing, the coercion they imply or the way in which they are implemented.
Whether through typologies or one of the approaches identified by Hood (1983) for the analysis of the instruments, the view provided by the sub-discipline of public policies under the paradigm of governance becomes important. This is because it recognizes the historical fact of "triple decentralization" (Fontaine, 2015, p. 63) that the State has passed through, as well as the causal relationship that exists between this fact and the proliferation of instruments of public intervention. In other words, under this broader view, the instruments are much more varied and complex than the legal norm that contains them, than the degree of coercion they possess, than the more technical or political character that guides them.

The "triple decentralization of the State" involves coordinating public action - and, consequently, the use of various instruments to implement it - with supranational agencies (top-down decentralization), with local governments through decentralization, deconcentration and administrative delegation (downwards decentralization), and with non-state stakeholders such as NGOs, social movements, private companies and the general public (decentralization to the outside). In other words, the view that public policies bring to the analysis of instruments allows us to understand what it means to govern today because it is not only to correct market imperfections, nor to control, order or redirect behaviors, but also to coordinate collective actions to solve very diverse and complex public problems.

It is about combating the neoliberal view of the instruments (very manageralist where the instruments that privilege the private and outsourcing are claimed as ideals) and which brings with it the so-called "flight from the State", without falling into a nostalgia for the centrality of the State, where coercion, the stick and regulation through rules are the ideal of intervention instruments. While it is true that the broadening of the range of intervention instruments makes it possible to adapt public action to the multidimensional nature of social problems, this is possible only with the emergence of governments increasingly able to respond to this nature and with the consolidation of a more active citizenry. In the words of Aguilar (2014), it 
Table 1. Some typologies of instruments

\begin{tabular}{|c|c|c|}
\hline Proponent(s) & Types of Instruments & Remarks \\
\hline Hood (1983) & $\begin{array}{l}\text { Nodality or Information } \\
\text { Authority } \\
\text { Treasury } \\
\text { Organization }\end{array}$ & $\begin{array}{l}\text { Known as the NATO Model, it refers to the resources available } \\
\text { to the State. }\end{array}$ \\
\hline $\begin{array}{l}\text { McDonnell and } \\
\text { Elmore (1987) }\end{array}$ & $\begin{array}{l}\text { Rules } \\
\text { Incentives } \\
\text { Training } \\
\text { Delegation }\end{array}$ & $\begin{array}{l}\text { It proposes strategies valid for any entity or organization, not } \\
\text { just for the State. }\end{array}$ \\
\hline $\begin{array}{l}\text { Schneider and } \\
\text { Ingram (1990) }\end{array}$ & $\begin{array}{l}\text { Authority } \\
\text { Incentive } \\
\text { Training } \\
\text { Symbolic or exhortative } \\
\text { Learning }\end{array}$ & $\begin{array}{l}\text { It proposes strategies valid for any entity or organization, for } \\
\text { not only the State, and takes into account the drivers of the } \\
\text { stakeholders for action in favor of politics. }\end{array}$ \\
\hline $\begin{array}{l}\text { Weimer and } \\
\text { Vining [1992] } \\
(2017)\end{array}$ & $\begin{array}{l}\text { Intervening on markets. } \\
\text { Stimulate } \\
\text { Regulate behavior } \\
\text { Producing a good or service (directly or by } \\
\text { third parties). } \\
\text { Providing public insurance }\end{array}$ & $\begin{array}{l}\text { Its typology refers to the various measures exclusively available } \\
\text { to the government to solve economic and social problems. }\end{array}$ \\
\hline $\begin{array}{l}\text { Doern and Phidd } \\
(1992)\end{array}$ & $\begin{array}{l}\text { Self-regulation } \\
\text { Exhortation } \\
\text { Expenditure } \\
\text { Regulation } \\
\text { Public property }\end{array}$ & $\begin{array}{l}\text { It emphasizes the degree of government intrusion into the } \\
\text { economy and postulates that there are only these five types of } \\
\text { instruments. }\end{array}$ \\
\hline Vedung (1998) & $\begin{array}{l}\text { Regulation (stick) } \\
\text { Economic means (carrot) } \\
\text { Information (sermon) }\end{array}$ & $\begin{array}{l}\text { A Minimalist typology that places the emphasis on the } \\
\text { mandatory nature of the State in its solution strategies. } \\
\text { Although it is a typology reminiscent of Hood's NATO model, } \\
\text { it deliberately leaves the "organization" resource out by } \\
\text { considering that this is "a prerequisite for the implementation } \\
\text { of a policy instrument and not a policy instrument in itself" } \\
\text { (p.15). }\end{array}$ \\
\hline Salamon (2002) & $\begin{array}{l}\text { Direct Government } \\
\text { Social regulation } \\
\text { Economic regulation } \\
\text { Contracting } \\
\text { Concession } \\
\text { Direct Loan } \\
\text { Loan Guarantee } \\
\text { Public insurance } \\
\text { Tax Expenditure } \\
\text { Fees, Charges } \\
\text { Legal obligations } \\
\text { Government Corporations } \\
\text { Vouchers or bonuses } \\
\text { Public Information }\end{array}$ & $\begin{array}{l}\text { More than a classification, these are the types of instruments } \\
\text { most used by governments according to the author, who } \\
\text { throughout the book he publishes classifies them based on the } \\
\text { evaluation criteria he proposes, such as automaticity, visibility, } \\
\text { coerciveness, among others. }\end{array}$ \\
\hline $\begin{array}{l}\text { Lascoumes and } \\
\text { Le Galès (2007) }\end{array}$ & $\begin{array}{l}\text { Legislative or regulatory } \\
\text { Economic and fiscal } \\
\text { Agreements and incentives } \\
\text { Information and communication } \\
\text { De facto and de jure best practices }\end{array}$ & $\begin{array}{l}\text { Through the resources mobilized by the State, this typology } \\
\text { aims at revealing the effects in terms of the political relations } \\
\text { and the legitimacy they make possible. }\end{array}$ \\
\hline
\end{tabular}




\begin{tabular}{|c|c|c|}
\hline Pal (2014) & $\begin{array}{l}\text { Doing nothing } \\
\text { Acting indirectly (Information, } \\
\text { Expenditure, Regulation) } \\
\text { Acting directly (Organization) }\end{array}$ & $\begin{array}{l}\text { "Deliberately eclectic" this typology highlights not only the } \\
\text { resources available exclusively to the State but also its capacity } \\
\text { to respond to problems, including the option of doing nothing. }\end{array}$ \\
\hline Velasco (2007) & $\begin{array}{l}\text { Organizational } \\
\text { Programmatic } \\
\text { Normative } \\
\text { Financial } \\
\text { Knowledge enhancement } \\
\text { Communication }\end{array}$ & $\begin{array}{l}\text { Takes into account the resources available to decision makers } \\
\text { to implement their initiatives. }\end{array}$ \\
\hline $\begin{array}{l}\text { Alfama and } \\
\text { Cruells (2011) }\end{array}$ & $\begin{array}{l}\text { Regulative } \\
\text { Informative } \\
\text { Participatory } \\
\text { Structural } \\
\text { Monitoring and evaluation } \\
\text { Economic } \\
\text { Formative }\end{array}$ & $\begin{array}{l}\text { This Classification responds more to the function of instruments } \\
\text { than to their own characteristics. }\end{array}$ \\
\hline $\begin{array}{l}\text { Howlett et al. } \\
(2006)\end{array}$ & $\begin{array}{l}\text { Information or Nodality } \\
\text { Authority } \\
\text { Treasury } \\
\text { Organization } \\
\text { General purpose of the use of the } \\
\text { instrument (substantive or procedural). }\end{array}$ & $\begin{array}{l}\text { They are based on Hood's typology, but they add two } \\
\text { dimensions to the instruments: a substantive one, which refers } \\
\text { to the impact of government through policy in the production } \\
\text { and delivery of goods and services to society; and a procedural } \\
\text { dimension that is related to the impact of the government on } \\
\text { the relations between state and non-state stakeholder. }\end{array}$ \\
\hline
\end{tabular}

would be not only smarter but more efficient to involve citizens in solving public problems of a complex nature, whose solution merits going far beyond the use of conventional government instruments (p. 90).

In short, according to Bercholc (2014), the new challenges of the state and public matters lead to their being confronted in an articulated manner with modern approaches to political science and sociology, as this will lead to:

More sophisticated and effective explanations, which in turn will allow the observation of inescapably interrelated and interdependent categories, where the appropriate is a systemic analysis that considers institutions, political and social stakeholders, and organizational and participatory processes, in constant communication and reciprocal influence ( $p$. 3)

\subsection{Participation instruments for the implementation of public policies}

According to the foregoing, it is proposed to think citizenship in a more active way that allows delving deeper into co-management, co-responsibility, the effectiveness of public policies and thus move - really - from governability to governance, as a public administration model that involves citizens in taking public decisions, which are less hierarchical than the previous traditional Weberian model, more transparent, open and participatory, where it is the duty of the citizen to participate in public debate through exercises of public reasonableness. Critical reasoning, political culture, deliberation and permanent participation in public affairs, politics and public policies are indispensable for this.

Thus, according to Oszlak (2009), the transformations that Latin America has experienced in the last twenty-five years, related to the transition from authoritarianism to democracy, from public management through processes to management by results and from centralization to decentralization, have influenced the increase in the degree of participation of the citizenship in the design and implementation of public policies, which, in turn, gives way to the category of participatory instruments for 
the implementation of public policies, such as citizen audiences, participatory budgets, citizen oversight offices, social control, surveillance committees, mobilizations, participatory planning, letters of commitment with the citizen, revocation of the mandate, opinion polls, among others (p. 23). All present in the different phases of the public policy cycle.

In other words, citizens are required to not simply become active at every election event, every four years in the elections of a democratically elected government, as is the case in the "model of delegative democracy" set out by O'Donnell (1994), where, after the elections, voters (delegators) become stone guests and a kind of passive audience that observes how governments govern - that is, with what instruments - but who do not engage or actively participate in decisionmaking about the ways. On the contrary, and following the author, the transition from democracy and the citizen to a truly institutionalized and consolidated democratic regime is required, which becomes an important decision point within the flow of political power (p. 8). Such democratic institutions must be tied to territorial decision-making and to the forms, roles and capacities related to access channels for such decision-making.

In the same sense, Kymlicka and Norman (1996) state that "a new citizenry is required in order to reverse the crisis of the citizenry" (p. 17). Thus, it is important to conceive participation as political action and as a right (Sancari, 2016, p. 19) where the former presumes to recognize it as the set of actions aimed at influencing the democratic political process, through voting, militancy in a political party, discussion, deliberation, even social protest and other non-institutionalized forms of political participation and, of course, the constant exercise of citizen control over power. On the other hand, participation understood as a right implies thinking it as a fundamental right that goes hand in hand with human dignity, autonomy and freedom and equality of individuals. This will necessarily combine principles of justice with concrete management practices, such as public policies and their instruments (Sancari, 2016, p. 30).

\section{Conclusions}

In short, public intervention instruments are devices that guide human behavior towards achieving certain objectives and, in that sense, constitute rules of the game, institutions that align public action. They are also tools to correct market failures and achieve economic efficiency. However, the instruments are not limited to this formal and technical institutional twodimensionality. Today, the study thereof must enable progressing towards context-sensitive governments, the diversity of stakeholders and the particularities of public issues. This implies embracing a broader approach, such as the one proposed by public policies.

The review of the literature on the subject leads to this conclusion insofar as such an approach is the most developed and takes into account not only the formal and purely technical dimensions of the instruments, but also the informal, ideological and political dimensions. Hence, it can be said that from public policies and governance, the study of instruments proceeds in a process of constant debate within an epistemic community, an environment that allows to analyze and study the instruments not only from the perspective of the design and implementation of policies but as a subject of study itself. In light of the above, after reviewing the state of the art of public intervention instruments, most literature on this subject is found to respond to an Anglo-Saxon and Eurocentric look. However, as Roth (2017) insisted, nowadays it is necessary to produce a greater number of works that delve deeper into the subject of public policies and their instruments from a Latin American perspective.

Likewise, it is necessary to establish the relationships between instruments and public policies and to study them within the framework of the public policy cycle, since this makes it possible to understand the types of public problems and the different courses of action of the government, which are reflected in certain instruments of intervention. In the words of Ballart and Ramió (2000), "public policies can use a wide variety of instruments" (p. 498), which means that the relationships between public policies and instruments are given by their 
role in the processes of materialization and implementation of public decisions. In summary, the analysis of the relationship between instruments and public policies, from the perspective of the process, allows the addition of other explanatory variables to the different forms of State intervention.

Finally, like the instruments of the market and direct government, it is now imperative to demand the instruments of participation, as these are necessary for the effectiveness and legitimacy of public policies within a governance framework. However, according to Oszlak (2009), the current challenge is to go beyond institutional developments in this regard, since the instruments of citizen participation for the design, formulation, implementation and evaluation of public policies are far from playing a predominant role (p.10). In short, the study of public intervention instruments, under the spotlight of public policies and especially of governance, allows us to observe them from a threefold dimension: political, technical and formal institutional.

\section{References}

Aguilar, L. F. (Ed.). (2013). Estudio introductorio. En L. F. Aguilar (Ed.), El estudio de las políticas públicas (pp. 15-74). México, D,F., México: Miguel Ángel Porrúa.

Aguilar, L. F. (2014). Estudio introductorio. En L. F. Aguilar (Ed.), La implementación de las políticas (pp. 15-92). México, D,F., México: Miguel Ángel Porrúa.

Alfama, E., \& Cruells, M. (2011). Evaluación y políticas transversales: el caso de las políticas de género. Recuperado de: https://www. academia.edu/2096222/Evaluaci\%C3\%B3n_y pol\%C3\%ADticas_transversales_el_caso_de las pol\%C3\%ADticas de g\%C3\%A9nero

Ariño, G. (2003). Principios de Derecho Público Económico. Modelo de Estado, Gestión Pública, Regulación Económica. Bogotá, Colombia/ Madrid, España: Universidad Externado de Colombia/Fundación de Estudios de Regulación.

Atehortúa, C. A. (2009). Servicios Públicos Domiciliarios, Proveedores y Régimen de Controles. Bogotá, Colombia: Universidad Externado de Colombia.

Balbín, C. (2015). Manual de derecho administrativo. Buenos Aires, Argentina: La Ley.
Ballart, X., \& Ramió, C. (2000). Ciencia de la administración. Valencia, España: Tirant lo Blanch.

Bardach, E. (2009). A practical Guide for Policy Analysis. The Eightfold Path to More Effective Problem Solving. Washington, USA: CQ Press.

Bercholc, J. (2014). Temas de Teoría del Estado. Buenos Aires, Argentina: Le Ley.

Bobbio, N. (1997). Estado Gobierno y sociedad. México D.F., México: Fondo de Cultura Económica.

Coase, R. (2002). El problema del costo social. En R. Andrés (Comp.), Derecho y Economía: una revisión de la literatura (pp. 512-557). México D.F., México: Impresora y Encuadernadora Progreso S. A.

Dahl, R., \& Lindblom,C. (1953). Politics, Economics and Welfare: Planning and Politico-Economic Systems Resolved into Basic Social Processes. Nueva York, USA: Harper and Row.

Doern, G., \& Phidd, R. (1992). Canadian Public Policy: Ideas, Structure, Process. Toronto, Canada: Nelson Higher Education.

Fontaine, G. (2015). El análisis de políticas públicas: conceptos, teorías y métodos. Barcelona, España/Quito, Ecuador: Anthropos Editorial/ FLACSO.

Insignares, R., Marín, M., Muñoz, G., Piza, J. R., \& Zornoza, J. J. (2007). Curso de derecho fiscal. Bogotá, Colombia: Universidad Externado de Colombia.

Hood, C. (1983). The Tools of Government. Chatham, USA: Chatham House Publishers.

Hood, C. (2006). The Tools of Government in the Information Age. In M. Moran., M. Rein, \& R. Goodin. (Eds.), The Oxford Handbook of Public Policy (pp. 469-481). Nueva York, USA: Oxford University Press.

Howlett, M., Kim, J., \& Weaver, P. (2006). Assessing Instrument Mixes through Program and Agency Level Data: Methodological Issues in Contemporary Implementation Research. Review of Policy Research, 23(1), 129-151.

Howlet, M, Mukherjee, I. (2017). Policy design: From tools to patches. Canadian public administration. Administration publique $d u$ canada, 60(1) 140-144.

Jessop, R. (2002). El futuro del estado capitalista. Madrid, España: Catarata.

Kirschen, E.S., Benard, J., Besters, H., Blackaby, F., \& Eckstein, O. (1964). Economic Policy in our 
Time. Amsterdam, North-Holland: Publishing Company.

Kymlicka, W., \& Norman, W. (1996) El retorno del ciudadano. Una revisión de la producción reciente en teoría de la ciudadanía. Cuadernos del CLAEH, (75), 81-112.

Lascoumes, P., \& Le Galès, P. (2007). Introduction: Understanding Public Policy through Its Instruments-From the Nature of Instruments to the Sociology of Public Policy Instrumentation. Governance: An International Journal of Policy, Administration, and Institutions, 20(1), 1-21.

Lascoumes, P., \& Le Galés, P. (2016). Instrumento. En J. I. Cuervo., J. F. Jolly, \& D. Soto. (Eds.), Diccionario de Políticas Públicas (pp. 342-351). Bogotá, Colombia: Universidad Externado de Colombia.

Leyva, S., \& Tabares, J. (2015). Un diagnóstico de los instrumentos de gobierno de una política pública. En S. Leyva (Ed.), Análisis de política púbica poblacional. La juventud en Medellín: crisis, cambios e innovación (pp.270301). Medellín, Colombia: Fondo Editorial Universidad EAFIT.

Linder, S., \& Peters, G. (1989). Instruments of government: Perceptions and contexts. Journal of Public Policy, 9(1), 35-58.

Linder, S., \& Peters, G. (1992). The Study of Policy Instruments. Policy Currents, 2, 1-7.

Linder, S., \& Peters, G. (1998). Conceptual frames underlying the selection of policy instruments. In G. Peters, \& F. van Nispen (Eds.), Public Policy Instruments: Evaluating the Tools of Public Administration (pp. 33-45). Cheltenham, Reino Unido: Edward Elgar.

McDonnell, L., \& Elmore, R. (1987). Getting the Job Done: Alternative Policy Instruments. Educational Evaluation and Policy Analysis, 9(2), 133-152.

Marín, F. (2008). Público y Privado: Estudio sobre las transformaciones del derecho, del estado y de la empresa. Bogotá, Colombia: Temis.

Miranda, A., \& Márquez, C. (2004). Intervención pública, regulación administrativa y economía: elementos para la definición de los objetivos de la regulación. Vniversitas, 53(108), 71-117.

Musgrave, R. (1994). Teoría múltiple de la hacienda pública. En J. F., Corona (Ed.), Lecturas de Hacienda pública. Madrid, España: Minerva Ediciones.

Mankiw, G. (2012). Principios de economía. México D.F., México: Cengage Learning.
O’Donnell, G. (1994). ¿Democracia delegativa? En G. O’Donnell (Ed.), Contrapuntos. Ensayos escogidos sobre autoritarismo ydemocratización (pp.287-304). Buenos Aires, Argentina: Paidós.

Oszlak, O. (2009) Implementación participativa de políticas públicas: aportes a la construcción de un marco analítico. En A. Belmonte (Ed.), Construyendo confianza. Hacia un nuevo vínculo entre Estado y Sociedad Civil (pp. 9-47). Buenos Aires, Argentina: Fundación CIPPEC/ Subsecretaría para la Reforma Institucional y Fortalecimiento de la Democracia, Jefatura de Gabinete de Ministros, Presidencia de la Nación.

Pal, L. (2014). Beyond Policy Analysis: Public Issue Management in Turbulent Times. Toronto, Canada: Nelson Higher Education.

Phelps, E. S. (1999). Economía política en texto introductorio. Barcelona, España: Antoni Bosch Editor.

Plazas, M. (2005). Derecho de la hacienda pública y derecho tributario. Bogotá, Colombia: Temis.

Restrepo, J. (2015). Hacienda pública. Bogotá, Colombia: Universidad Externado de Colombia.

Roth, A. N. (2017). Políticas Públicas. Formulación, Implementación y Evaluación. Bogotá, Colombia: Ediciones Aurora.

Salamon, L. M. (2002). The Tools of Goverment. A guide to the New Governance. Nueva York, Estados Unidos: Oxford University Press.

Sancari, S. (2016). La participación política en la Argentina contemporánea. Buenos Aires, Argentina: Editorial Departamento de Publicaciones de la Facultad de Derecho UBA/ La Ley.

Schneider, A., \& Ingram, H. (Mayo de 1990). Behavioral Assumptions of Policy Tools. The Journal of Politics, 52(2), 510-529.

Santofimio, J. O. (1998). Ministerio Público, Tratado de Derecho Administrativo: Acto administrativo, procedimiento, eficacia y validez. Bogotá, Colombia: Universidad Externado de Colombia.

Suárez, D. (2010). Huida o vigencia del derecho administrativo: el caso de los servicios púlibcos domiciliarios. Transformaciones-tendencias del derecho administrativo. Medellín, Colombia: Universidad de Antioquia.

Stiglitz, J., \& Rosengard J. (2016). La Economía del Sector Público. Madrid, España: Antoni Bosch editor.

Sunstein, C. (2014). (más) Simple. El futuro del 
gobierno. Madrid, España: Marcial Pons.

Vedung, E. (1998). Policy instruments: typologies and theories. In M. L. Bemelmans-Videc, R. C. Rist, \& E. Vedung (Eds.), Carrots, sticks and sermons. Policy instruments and their evaluation (pp. 21-58). New Brunswick, USA: Transaction publishers.

Varian, H. (2005). Microeconomía intermedia. Un enfoque moderno. Barcelona, España: Editorial Antoni Bosch.
Velasco, M. (2007, sep.). Distintos instrumentos para un mismo fin. Los instrumentos de las políticas públicas como herramienta para el análisis. VIII Congreso Español de Ciencia Política y de la Administración, Asociación Española de Ciencia Política y de la Administración, Valencia, España.

Weimer D. L., \& Vining A. R. (2017). Policy Analysis: Concepts and Practice. Nueva Jersey, USA: Prentice Hall.

¿How to quote this article?

Franco Vargas, M. H., \& Roldán Restrepo, D. (2019). The instruments of public policy. A transdisciplinary look. Cuadernos de Administración, 35(63), 101-113. DOI: https://doi.org/10.25100/cdea.v35i63.6893 